\title{
精密高温測定の技術と解析
}

\author{
名古屋工業大学先進セラミックス研究センター＼cjkstart石澤伸夫
}

\section{Nobuo ISHIZAWA: Techniques and Methodologies for Precise Diffraction-Experiments at High-Temperatures}

High-temperature single-crystal X-ray diffraction studies done recently in our group are briefly reviewed from the viewpoint of the techniques and methodologies employed.

\section{1. 二次元検出器を備えた単結晶回折計を用いる ときの留意点}

高温における単結晶の構造変化を調べるときは二次 元検出器を備えた単結晶X線回折計が便利である。 その 理由の 1 つは, ゼロ次元検出器 (ポイントディテクター) に比べて「面」で走査する分だけ，比較的短時間で測定 を終了できるからである. 二次元検出器としてはイメー ジングプレート (IP) やCCD型X 線検出器など積分型の X線検出器が使われてきた. ${ }^{1}$ しかし最近ではX線光子を $1 つ 1 つ$ 検出できるパルス型二次元 X線検出器も現れ, 今後の展開が楽しみである.

二次元検出器を備えた単結晶回折計を用いて得られ た大量のフレームデータを計算機処理する際は, 格子定 数や回折強度など, 結晶構造そのものにかかわる本質的 な諸量の算出と同時に, 検出器の位置, 歪み, 回折計の 中心からの結晶の位置のずれなど, 多くの装置パラメー 夕も精密化される。このとき, どのような装置パラメー 夕が精密化され，どのようなものが固定されるか，ある いは拘束されるか, すなわちフレームデータを解析する ソフトウェアはいったい何をしているかを正確に把握す る必要がある。もっとも, 室温における一点限りの測定 で, 単位胞サイズのあまり大きくない結晶の未知構造を ざっくりと決定する場合には, このことはほとんど問題 にならない. 回折計に付属するソフトウェアのデフォル トのルーチンはそういう場合に特化されているからで ある。

しかし，結晶の単位胞がかなり大きかったり，1つの 結晶軸の長さが異常に長かったり，擬対称を示したり， 複雑な双晶構造をとったりする場合などでは問題が生じ ることがある。またその逆に, ダイヤモンドやシリコン など逆空間に扔ける格子点密度の小さい完全性の高い 結晶でも, デフォルトの設定では解析に驚くほど困難を きたすことがある，試料温度を細かく変えて測定を繰り

日本結晶学会誌 第61巻 第3 号 $(2019)$
返す高温構造解析も同様に難しい場合がある，次節では 変調構造をもつ結晶の温度变化を調べた例について述 べる. 実験装置は CCD 型X線検出器を備えたブルカー 社のSmart Apex2である. 二次元検出器から得られたフ レームデータの解析には同装置に付属するプログラムで あるSAINTを用いた。

\section{2. 変調ベクトルの温度依存性}

$\mathrm{La}_{2} \mathrm{Ti}_{2} \mathrm{O}_{7}$ は $1,735 \mathrm{~K}$ という高いキュリー温度をもつ強 誘電体で, 近年では, 水の全分解にかかわる光触媒特 性についても注目されている. 既往の研究によると, $\mathrm{La}_{2} \mathrm{Ti}_{2} \mathrm{O}_{7}$ は $1,000 \mathrm{~K}$ 付近に隣接する 2 つの相転移 ${ }^{3)}$ があ り, この狭い温度域に打いて変調べクトル $\mathbf{q}=\alpha \mathbf{a}^{*}(\alpha \sim$ 0.49）をもつ $3+1$ 次元の変調構造を示すことが知られ ている.4)

最近の研究 ${ }^{5)}$ によると空間群 $P 112$ をとる低温相 (L) の $\mathrm{La}_{2} \mathrm{Ti}_{2} \mathrm{O}_{7}$ 結晶を加熱していくと $989 \mathrm{~K}$ 付近から超空 間群 $C m c 2_{1}(\alpha 00) 0 \mathrm{~s} 0 ； \alpha \sim 0.49$ で記述される変調構造 相 (IC) が出現し始め, 低温相 (L) との2 相共存領域に 入る. この 2 相共存領域に扔いて L 相を特徵づける超構 造反射の平均反射強度は昇温とともに急激に減少し, $1,027 \mathrm{~K}$ に扔いて完全に消失する。一方, IC相を特徵づけ る衛星反射の平均強度は 2 相共存領域で徐々に増加し, $\mathrm{IC}$ 相の単相になる $1,027 \mathrm{~K}$ で最強になる. しかしその温 度に扔いても $\sin \theta / \lambda<0.70$ の逆空間に打ける全衛星反 射の強度の和は全基本反射の強度の和の $2 \%$ に満たな い(関連論文5)の Fig. 2 参照)。ささらに昇温すると衛星反 射の平均強度は直線的に減少し, $1,080 \mathrm{~K}$ 付近でゼロと なり, 結晶は基本反射のみからなる空間群 $C m c 2_{1}$ の高温 相 $(\mathrm{H})$ に変化する. IC相の出現する温度領域は狭く, ま た, 衛星反射の強度そのものも弱いため, L- $\mathrm{IC}-\mathrm{H}$ 逐次 相転移に伴う結晶構造の温度変化を知るには, 高度の 測定・解析技術を必要とした。

図 1 は $\mathrm{La}_{2} \mathrm{Ti}_{2} \mathrm{O}_{7}$ の IC 相における変調べクトルの係数 

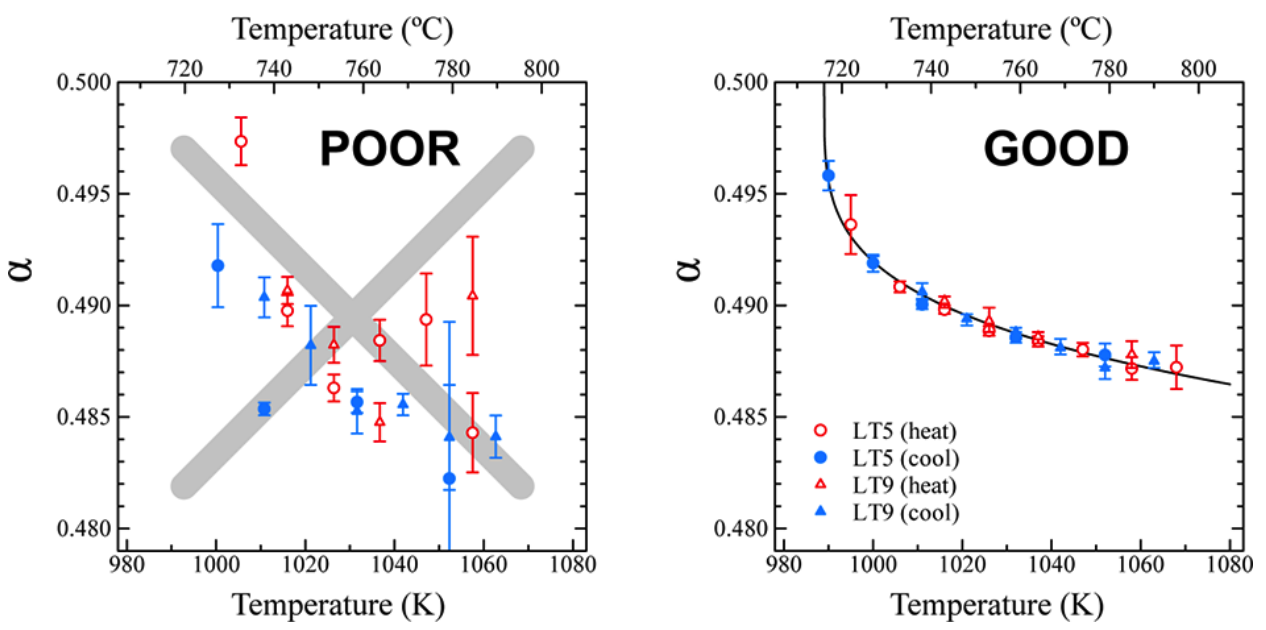

図 $1 \mathrm{La}_{2} \mathrm{Ti}_{2} \mathrm{O}_{7}$ の $3+1$ 変調構造相における変調ベクトル $\mathbf{q}=\alpha \mathbf{a} *$ の係数 $\alpha$ の温度依存性. (Temperature dependence of $\alpha$ in the modulation vector $\mathbf{q}=\alpha \mathbf{a}^{*}$ in the $(3+1)$-modulated phase of $\mathrm{La}_{2} \mathrm{Ti}_{2} \mathrm{O}_{7}$. ) 左図は研究初期に得られた誤差の大 きい解析結果で, 右図はフレームデータの解析を適切に行って得られた, より正確で誤差の小さい解析結果を 示す.

$\alpha$ の温度依存性の測定例である. POOR と大書した左図 は実験開始当時のもので, 装置パラメータなどの精密化 も含め, ほぼデフォルトに近い計算プロセスにより得ら れたものである. 左図では $\alpha$ の温度依存性が不明暸であ る.また，このようなやり方で得られた格子定数の温度 変化もばらつきが大きかった(この研究では格子定数の 4 桁目の数字を正しく求める必要がある.すなわち 5 桁 目の誤差を抢よそ土2以下にする必要があった）。そこ で，まず室温で長時間測定した最も上質と思われるデー タセットから各種装置パラメータを決定し，これを同 一結晶に対する他の温度のデータに対しても適用した。 高温で得られた短時間測定のフレームデータの解析に は, 温度依存性を示す重要なパラメー夕（具体的には格 子定数, 変調ベクトル係数 $\alpha$, および回折計中心からの 結晶位置のずれ）のみを精密化させた。こうして図1の GOOD と書いてある右図のような結果が得られた。変調 ベクトルの温度変化は明瞭であり, 2 つの結晶試料 (LT5 およびLT9）を用いた独立な解析結果（実験時期および 実験者も異なる)を重ねて描いてあるにもかかわらず，両 者の違いはほとんどない. また昇温過程・降温過程によ る差異もほとんど存在しなかった，得られた結果から変 調べクトル係数 $\alpha$ は温度に対してほぼ $1 / 4$ 乗で変化する ことがわかり，相転移の機構に関する議論が可能になっ た. $\mathrm{La}_{2} \mathrm{Ti}_{2} \mathrm{O}_{7}$ は層状ペロフスカイト構造をもつ $\mathrm{A}_{2} \mathrm{~B}_{2} \mathrm{O}_{7}$ 型 化合物の一種で，その相転移は $\mathrm{BO}_{6}$ 八面体の三次元的 な連鎖をもつ $\mathrm{ABO}_{3}$ 型ペロフスカイト構造よりもさらに 複雑であり，低温側に多くの多形が報告されている。こ の原因の 1 つとして IC 相に存在する単位胞サイズの双晶 構造とその温度に伴う盛衰が関連する可能性があると推 定された。

\section{3. 確率密度関数}

結晶構造の精密化に際しては独立原子モデル （Independent Atom Model；IAM）を仮定することが一般 的である。また，各原子の熱振動には等方性や非等方性 の調和振動子を仮定することが多い. しかし, 高温では 原子の熱振動が大きくなり, このような調和振動子モデ ルでは構造の正しい把握が難しくなることがある。この 節では原子の確率密度関数をより高次の項まで用いた 方解石 (calcite) の高温相の解析例6) について述べる.

一般に回折波の振幅は散乱体密度のフーリエ変換で 表される.7) IAMにおいて, 散乱体密度極大の動的分布 に依存する項は原子変位因子と呼ばれ, 確率密度関数 (Probability density function; $P d f$ ) のフーリエ変換として 次式で与えられる。

$$
T(\mathbf{h})=\int_{-\infty}^{\infty} P d f(\mathbf{u}) \exp (2 \pi i \mathbf{h} \cdot \mathbf{u}) d \mathbf{u}
$$

ここで, $\mathbf{h}$ は散乱ベクトル， $\mathbf{u}$ は散乱体密度極大の位置べ クトルである. 確率密度関数 $(P d f)$ を表現するための展 開関数にはいろいろあるが, 一番簡易なモデルはGauss 関数を用いる調和振動近似である. 非調和振動解析で は確率密度関数の展開関数として高次の Gram-Charlier 級数を用いる場合がある。原子の確率密度関数を 3 次 の Gram-Charlier 級数を用いて表現すると以下のように なる。

$$
\begin{aligned}
\operatorname{Pdf}(\mathbf{u})= & \left\{1+\frac{1}{3 !} c^{i j k}\left(w_{i} w_{j} w_{k}-w_{i} s_{j k}-w_{j} s_{k i}-w_{k} s_{i j}\right)\right\} \\
& \cdot \sqrt{\frac{\operatorname{det}\left(\left(s_{i j}\right)^{-1}\right)}{(2 \pi)^{3}}} \exp \left(-\frac{1}{2} \mathbf{u}^{t}\left(s_{i j}\right)^{-1} \mathbf{u}\right)
\end{aligned}
$$




$$
w_{i}=\left\{\left(s_{i j}\right) \mathbf{u}\right\}_{i}
$$

$$
s_{i j}=U_{i j} a_{i}^{*} a_{j}^{*}
$$

ここで, $a_{i}^{*}$ は逆単位胞の各辺の長さ, $c^{i j k}$ は 3 次の展開係 数であり, $U_{i j}$ は調和振動近似で得られる原子変位因子 の $U$ 表現と呼ばれる 3 行 3 列の分散共分散行列の係数, $\left(s_{i j}\right)$ は $s_{i j}$ の行列表現である.

式（2）を用いて求めた各原子の確率密度関数を炭酸 基の3 個の酸素についてさらに重ねた連結確率密度関数 (joint-probability density function $)^{8)}$ を図 2 に示す。この図 は連結確率密度関数を $3 つ の$ 等数值面に分けて表示した もので, 外側の透明に近い色の等密度面は積分したとき にその内部に $90 \%$ の酸素が存在することを示し, その内 側の面は内部に $50 \%$ の酸素が存在することを示し，一 番内側の濃い色の等密度面は内部に $10 \%$ の酸素が存在 することを示している. 方解石は高温で可逆的な I-IV$\mathrm{V}$ 逐次相転移を起こす. 左端の絵は, I相の $891 \mathrm{~K}$ におけ る炭酸基であり，3個の酸素原子がそれぞれ独立に，炭 酸基の平面から少し斜めの方向により大きく振動してい る様子がわかる．I相は調和振動子モデルが良い近似で

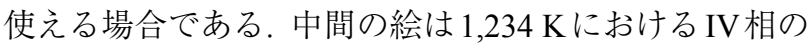

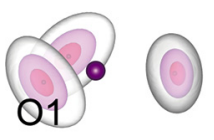

calcite-I at $891 \mathrm{~K}$



calcite-IV at $1234 \mathrm{~K}$



calcite-V at $1275 \mathrm{~K}$
図2 方解石中の炭酸基の酸素の連結確率密度関数. (Joint-probability density function of the oxygen atoms in the $\mathrm{CO}_{3}$ group of calcite.) 白, 桃色, 赤の等 密度面で囲まれた内部にはそれぞれ90，50，10\% の酸素原子を含む. 編集部注 : カラーの図は電子 版を参照下さい.

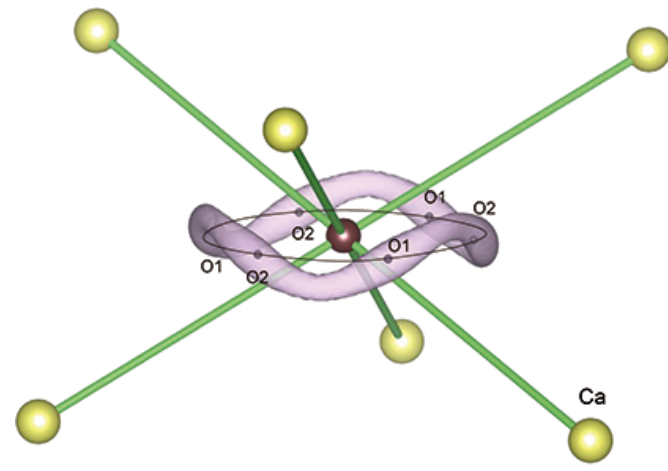

$\mathrm{O} 1$ and $\mathrm{O} 2$ positions in calcite
もので, 酸素が $\mathrm{O} 1$ 席と $\mathrm{O} 2$ 席の 2 力所の位置に統計的に 分布している.1つの炭素の周りの3つの酸素はO1（と その等価な席) の周りで振動しているか, あるいは $\mathrm{O} 2$ 席 (とその等価な席) の周りで振動しているかのどちらか である. IV相では, いわゆるスプリットアトムモデルを 用い, 調和振動を仮定してもなんとか解析はできる。し かし同様な方法で $\mathrm{V}$ 相を解釈することは難しい.6),9)

図2右の1,275 KのV相では酸素は炭素の周りで波を 打ったような軌道の周りに一様に分布している. I相のよ うに $\mathrm{O} 1$ 席にのみ存在するとか, IV 相のように $\mathrm{O} 1$ 席ある いはO 2 席に統計的に存在するとかという「酸素位置の 局在性」は失われている. 酸素が最も高い確率で存在す るところは, 炭素の周りの「うねつた円軌道」(undulated circular orbital）上にあって特定できない. 散乱体の確率 密度分布はボルツマン統計を仮定することで有効一粒子 ポテンシャルに変換することができる.77,8)

$$
V_{\text {eff }}=-k_{\mathrm{B}} T \ln \left(\frac{P d f(\mathbf{u})}{P d f\left(\mathbf{u}_{0}\right)}\right)
$$

ここで $k_{\mathrm{B}}$ はボルツマン定数, $\mathbf{u}_{0}$ は零ベクトルである. 連 結確率密度分布からこの軌道に沿ったポテンシャルエ ネルギーを算出すると, うねった円軌道上の点はすべて 最低值（ゼロ）になる，換言すればこの軌道上であれば 酸素はどこにいても等しく安定である.この意味で $\mathrm{V}$ 相 の結晶中では酸素は副格子溶融を起こしていると言え るであろう。一方，このような高温においても，1つの炭 酸基の 3 個の酸素は相互に等距離を保ち, また中心炭素 からも等距離を保っていると考えられる.すると, V相 の酸素のうねった円軌道は, 3 個の酸素が傘反転を繰り 返しながら炭素の周りを回転することを示唆している (動画 1 参照)。すなわち炭素も含めた炭酸基分子は高温 で平面性を大きく失う瞬間が周期的に生じる。もちろん 十分な時間平均をとればその平面性は保たれている. 方解石 (calcite-I) や霰石 (aragonite) などの炭酸カル

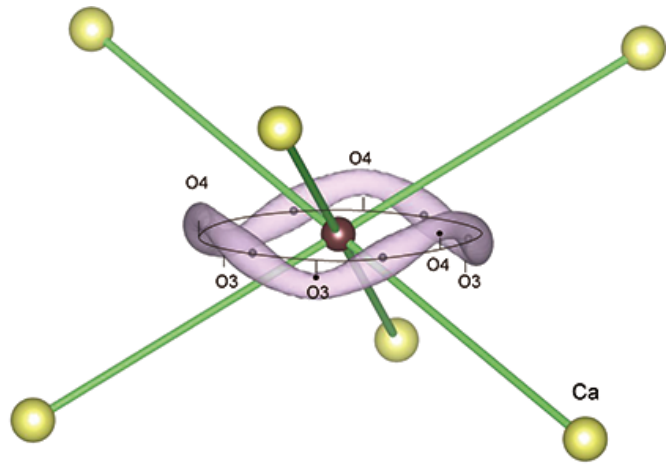

$\mathrm{O} 3$ and $\mathrm{O} 4$ positions in aragonite

図3 方解石 $\mathrm{V}$ 相における八面体型カルシウム包接体中の酸素のうねった円軌道とこれに対応する方解石 $(\mathrm{O} 1 / \mathrm{O} 2$ 席) および霰石 (O3/O4席) 中の酸素位置. (Undulated circular orbital of oxygens of the $\mathrm{CO}_{3}$ group in the octahedral calcium cage in calcite- $\mathrm{V}$, showing the corresponding oxygen positions $\mathrm{O} 1 / \mathrm{O} 2$ in calcite and $\mathrm{O} 3 / \mathrm{O} 4$ in aragonite.) 
シウムの結晶構造を, 1 つの炭酸基が 6 個のカルシウム からなる八面体の中に包接されたものと考えることがで きる. 方解石と霰石ではその包接体の積み上げ方も異な るが，1つの包接体の中における炭酸基の向きもまた異 なっている、V相の酸素のうねった円軌道を眺めると, 方解石における位置 ( $\mathrm{O} 1$ 席あるいは $\mathrm{O} 2$ 席など, 軌道の うねりの中心となる位置) と霞石に拀ける位置 (O3 席あ るいは $\mathrm{O}$ 席など, 軌道のうねりの最大ないし最小とな る位置) が含まれていることがわかる（図3），すなわち $\mathrm{V}$ 相は方解石と霞石の中間に位置する遷移的構造とみ なすことができよう，そしてこの遷移的構造の出現は方 解石の高温に抢ける $\mathrm{c}$ 軸方向の異常な伸びと密接に関係 している (関連文献6)の Fig. S1 参照). 方解石と霞石の 生成関係には謎の部分が多かったが, $\mathrm{V}$ 相の存在とその 構造の解明を待って初めて本格的な研究が開始された と言ってよい.

\section{TLS 補正}

最小二乗法による構造の精密化というプロセスにお いて，われわれは原子をしばしば「球」と仮定する。原 子の散乱因子に対しても一般的にはそうであるし，原 子変位因子に対してもそう仮定する場合がある。そし て「球」同士の相互作用は無視する (独立原子モデル). このような最小二乗法では, たとえ異方性の原子変位因 子を用いても原子座標が真值に収束せず，結合距離が 正しく求まらない場合がある. 方解石もその一例で, 結 合している原子間の変数相関を考慮しない通常の最小 二乗法では炭酸基中の $\mathrm{C}-\mathrm{O}$ 結合距離は高温側で短めの 值になる。これを解決する 1 つの方法はTLS 解析と呼ば れるもので, 分子を構成する原子の変位変数を独立に 動かさず，代わりに分子の対称性を考慮し，分子全体の 並進 (Translation), 秤動 (Libration)，㧍よびねじ的動き (Screw：厳密には並進テンソルと秤動テンソルの相関倸
数)を変数として用いる. 独立原子モデルを「球」モデル と呼ぶなら, TLS モデルは「球と棒」モデルと呼べよう。 TLS 解析法の原理は原著論文, ${ }^{10)}$ あるいは書物7) に譲り, 結果のみを述べる。

異方性原子変位パラメー夕を用いる通常のIAM解析 法で得られた方解石中の $\mathrm{C}-\mathrm{O}$ 距離の温度変化を図 4 左 に示す．同じデータに対してTLS解析を行った場合の 結果を図4右に示す，通常の IAM解析では，C-O 結合距 離が昇温とともに小さくなるのに対し, TLS 補正を行う と, 昇温とともに緩やかに増加する. 室温付近での両者 の違いはそれほど大きくないが, $1,200 \mathrm{~K}$ 付近ではその 違いは掠よそ $0.08 \AA$ 程度に拡大する。この差は大きい。 なお，TLS補正して得られた原子間距離がより真值に近 いことは，ほかの手法を用いた結合距離の推定結果 ${ }^{11)}$ か らも担保されている. な招, 方解石のI相と IV 相の解析 ではTLS 補正が有効に機能した。しかしV相ではいささ か怪しい(図4右)。これは, V相に打ける酸素の原子変 位の大きさが, TLS 補正の限界7)を超えていることもあ るが, より根本的には, 副格子溶融を起こしているV相 の構造が, 通常の「球」モデルはもとより, TLS解析が前 提とする「球と棒」モデルをも超越していることによる のであろう.

\section{5. シリコン・アバランシェフォトダイオード検出器}

測定可能なすべての反射の積分強度を正確に測定す るには, 1 つつの反射を回折計の赤道面にのるように 結晶の方位を制御し，一定の角速度でエバルト球を切る ようにして逆格子点の強度分布を求める手法, すなわち 四軸型単結晶回折計などを用いた $2 \theta-\omega$ 走查法が古典的 で, 時間は掛かるが優れた手法である. 問題は, いわゆ るポイントデイテクターと呼ばれるX線検出器にある. 無機結晶に扔ける回折強度のダイナミックレンジは広 く, 例えばよく使われる $\mathrm{NaI}(\mathrm{Tl})$ シンチレーション検出
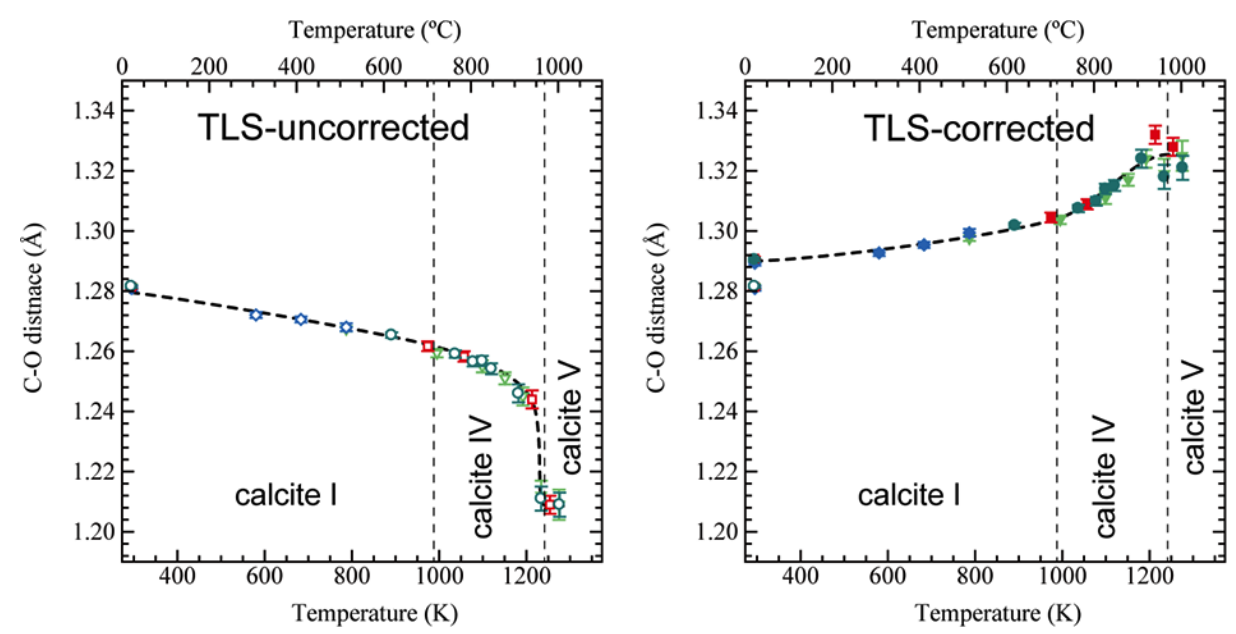

図4 高温に扔ける方解石の $\mathrm{C}-\mathrm{O}$ 結合距離の温度変化. (The $\mathrm{C}-\mathrm{O}$ interatomic distance in calcite as a function of temperature.) 左図はTLS 補正を行わなかった結果で, 右図は行った結果を示す. 
器の発光効率は〜 $250 \mathrm{~ns}$ と長く, 少し X線が強くなると もう間に合わない(数え落とす) 場合があり，X線経路 に減衰板や吸収板などを入れて本末転倒的なことをしな ければならない。しかし岸本らによって開発された8枚 積層型のシリコン・アバランシェフォトダイオード検出 器を使えば毎秒 $1 \sim 10^{9}$ 個の X線光子をほほ正確に計数 できるようになり，先に述べた減衰板や吸収板を完全に 駆逐した.12)-14)この検出器は放射光実験施設BL-14Aの 四軸型回折計に組み込まれ，無機結晶の精密構造解析 に使用されている. 次節では同装置を用いた測定例の 1 つとして $\mathrm{LiMn}_{2} \mathrm{O}_{4}$ の相転移 ${ }^{15)}$ について述べる.

\section{6. $\mathrm{LiMn}_{2} \mathrm{O}_{4}$ の相転移}

$\mathrm{LiMn}_{2} \mathrm{O}_{4}$ はリチウムイオン電池の正極材料の母体結晶 の1つとして広く知られている. 室温付近にやや緩慢な 相転移があり, 低温相のLiイオン伝導性はきわめて低い が，この構造を理解することが高温相におけるLiイオン の結晶内拡散を理解する手掛かりとなる.

$\mathrm{LiMn}_{2} \mathrm{O}_{4}$ の高温相は通常の立方晶系スピネルの構造 (空間群 $F d \overline{3} m$ ) をとり, 低温相は $3 \times 3 \times 1$ の超構造（空 間群 $F d d d)$ をとる。低温相の Mn 席には Mn1 から Mn5ま での独立な $\mathrm{Mn}$ 席があり, そのうち $\mathrm{Mn} 1$ と $\mathrm{Mn} 3$ 席には3 価の $\mathrm{Mn}^{\mathrm{III} か ゙, ~} \mathrm{Mn} 4$ と $\mathrm{Mn} 5$ 席には4価の $\mathrm{Mn}^{\mathrm{IV}}$ が入り，そ の電荷はほとんど変動しないと考えられる，一方 $\mathrm{Mn} 2$ 席は 3 価と 4 価の両方の状態をとり (原子価摇動), その 時間平均は 3.25 価である. 4 個の Mn2 と 4 個の酸素 (O9) からなるへテロキュバン型クラスターは分子ポーラロン を形成し，4個の Mn2 の $e_{\mathrm{g}}$ 由来軌道に 3 個の電子が共有 され, $\mathrm{Mn} 2$ の電荷が時間平均值として $3.25\left(\mathrm{Mn}^{\mathrm{IV}}: \mathrm{Mn}^{\mathrm{III}}\right.$ $=1: 3)$ になっていると推定される.この $e_{\mathrm{g}}$ 由来軌道は スピンの向きを揃えて $a$ 軸方向に規則配列し, 一軌道当 たり平均 $3 / 4$ 個の電子が入り, 弱いヤーンテラー歪を $a$ 軸方向に示す. 別な表現をすると, ヘテロキュバン型ク ラスター内に $\mathrm{Mn}^{\mathrm{III}}$ が 3 個, $\mathrm{Mn}^{\mathrm{IV}}$ が1個あり，この位置関 係が時刻とともに変化するが, ヤーンテラー軸は常にa 軸方向に揃っており, $e_{\mathrm{g}}$ 由来軌道における電子の有無に 依存して Mn-O結合距離が $a$ 軸方向に伸びたり縮んだり する結合長摇動を起こす (図5および動画2参照).

この $3 \times 3 \times 1$ 型低温相に扮ける $\mathrm{Mn}^{\mathrm{IV}}$ の配列を $\mathrm{c}$ 軸方 向から眺めると, アルキメデスの正多角形による 8 種類 の平面充填の 1 つである正方形 1 枚, 正八角形 2 枚から構 成される $(4,8,8)$ 型タイルの目地の頂点位置に $\mathrm{Mn}^{\mathrm{IV}}$ が 分布している (図6). Mnの原子価摇動が生じているへ

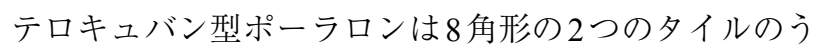
ちの 1 つに閉じ込められている. 残るもう 1 種類の 8 角形

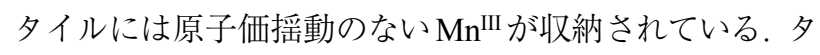
イルの目地の各頂点にある $\mathrm{Mn}^{\mathrm{IV}}$ はスピンブロッケード を構築し, 原子価摇動と結合長摇動が起きているへテロ

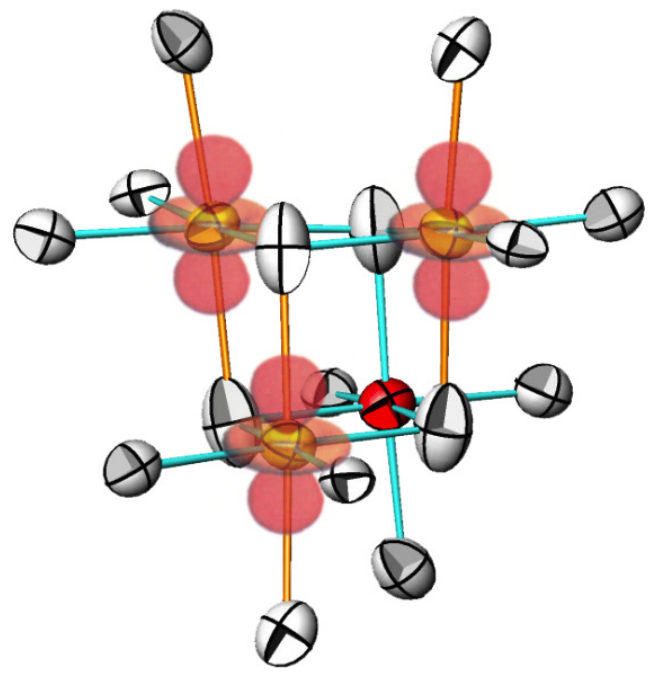

図5 ヘテロキュバン型 $\mathrm{Mn}_{4} \mathrm{O}_{4}$ クラスターにおける $\mathrm{Mn}$ の原子価摇動 $\left(\mathrm{Mn}^{\mathrm{III}}\right.$ は $e_{\mathrm{g}}$ 由来軌道に入る電子を 図案的に表示, $\mathrm{Mn}^{\mathrm{IV}}$ は赤い変位棈円体) と周辺 酸素も含めた結合長摇動の模式図. (Schematic structure of the heterocubane $\mathrm{Mn}_{4} \mathrm{O}_{4}$ cluster and surrounding oxygens, showing the fluctuations of the Mn oxidation-states and Mn-O bond-lengths.) 編集部 注：カラーの図は電子版を参照下さい.

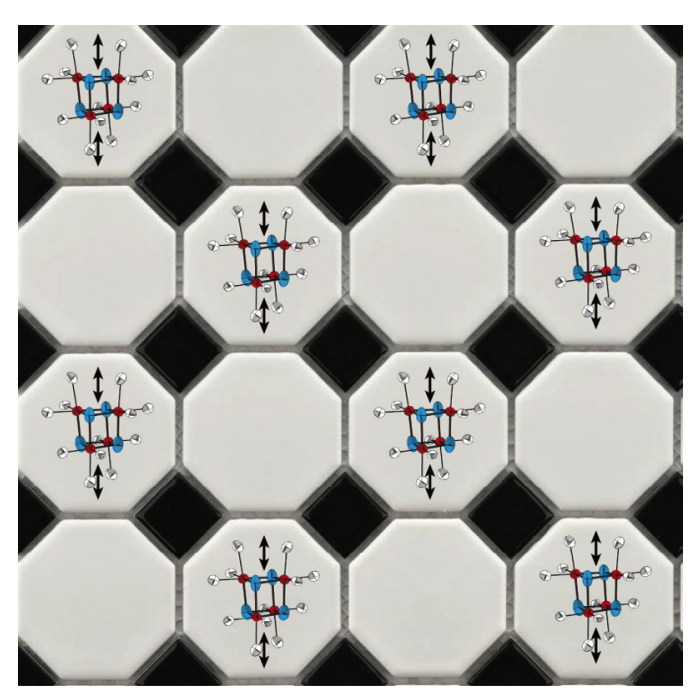

図61つの正方形 (黒色) および2つの正八角形 (死色) からなるアルキメデスの $(4,8,8)$ 型の平面充填に 基づくタイル模様 (図の縦と横は $\mathrm{LiMn}_{2} \mathrm{O}_{4}$ 低温相 の $a$ と $b$ 軸長にそれぞれ対応). (The (4,8,8)-type Archimedean tiling pattern composed of a square (black) and two octagons (grey) with corners occupied by $\mathrm{Mn}^{\mathrm{IV}}$, in the low-temperature form of $\mathrm{LiMn}_{2} \mathrm{O}_{4}$.) 低温 相の $\mathrm{Mn}^{\mathrm{IV}}$ はタイルの目地の各頂点に位置し, 原子 価摇動掞よび結合長摇動を示すへテロキュバン型 ポーラロンが正八角形の1つのタイル内に閉じ込 められている様子を模式的に示す. 編集部注 : カ ラーの図は電子版を参照下さい. 


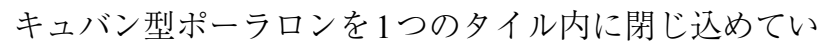
る。しかし高温になって相転移すると, このスピンブロッ ケードが溶け, 結合長摇動を起こしているポーラロンは, 結晶内を自由に泳ぎ回ることができる。これが Liの拡 散を容易にしている原因であると推定された. $\mathrm{LiMn}_{2} \mathrm{O}_{4}$ の相転移はへテロキュバン型ポーラロンの規則 -不規則 相転移とみなすことができる。

最近になって, $\mathrm{LiMn}_{2} \mathrm{O}_{4}$ 中の $\mathrm{Mn}$ の混合原子価問題を 異常分散効果を利用した放射光粉末回折データから直 接解明しようとする試みが報告された. ${ }^{16)}$ 今後の発展が 期待される.

\section{7. 補遺}

構造解析にはXtal, ${ }^{17)} \mathrm{JANA} 2006^{18)}$ などのプログラム パッケージを用いた。連結確率密度関数などの三次元数 值データの可視化にはVESTA, ${ }^{19)}$ Mathematica $^{20)}$ などを 用いた。ここに挙げた研究例はいずれも筆者が最近かか わったものであり, 編集委員会からいただいた掲題を網 羅するものではないが, この小稿が無機結晶の高温構造 研究の今後の進展に何らかの役に立てば幸いである.

\section{文 献}

1) 雨宮慶幸, 伊藤和輝：日本結晶学会誌 45, 163 (2003).

2) P. Kraft, A. Bergamaschi, C. Broennimann, R. Dinapoli, E. F. Eikenberry, B. Henrich, I. Johnson, A. Mozzanica, C. M. Schlepütz, P. R. Willmott and B. Schmitt: J. Synchrotron Rad. 16, 368 (2009).

3) S. Nanamatsu, M. Kimura, K. Doi, S. Matsushita and N. Yamada: Ferroelectrics 8, 511 (1974).

4) M. Tanaka, H. Sekii and K. Ohi: Jpn. J. App. Phys. 24, 814 (1985).
5) N. Ishizawa, K. Ninomiya and J. Wang: Acta Cryst. B75, 257 (2019).

6) N. Ishizawa, H. Setoguchi and K. Yanagisawa: Sci. Rep. 3, 2832 (2013).

7) B. T. M. Willis and A. W. Pryor: Thermal vibrations in crystallography, Cambridge University Press, London (1975).

8) U. H. Zucker and H. Schulz: Acta Cryst. A38, 568 (1982)

9) 石澤伸夫：J. Flux Growth 8, 52 (2013).

10) V. Schomaker and K. N. Trueblood: Acta Cryst. B24, 63 (1968).

11) P. Gillet, C. Biellmann, B. Reynard and P. McMillan: Phys. Chem. Miner. 20, 1 (1993).

12) S. Kishimoto, N. Ishizawa and T. P. Vaalsta: Rev. Sci. Instrum. 69, 384 (1998).

13) S. Kishimoto: J. Synchrotron Rad. 5, 275 (1998).

14）岸本俊二 : 放射光 21, 320 (2008).

15) N. Ishizawa, K. Tateishi, S. Oishi and S. Kishimoto: Am. Mineral. 99, 1528 (2014).

16) M. Tanaka, K. Yubuta, Y. Katsuya and O. Sakata: AIP Conference Proceedings 2054, 050011 (2019).

17) S. Hall, D. du Boulay and R. Olthof-Hazekamp: Gnu Xtal System. http://xtal.sourceforge.net (2002).

18) V. Petříček, M. Dušek and L. Palatinus: Z. Kristallogr. 229, 345 (2014).

19) K. Momma and F. Izumi: J. Appl. Cryst. 44, 1272 (2011).

20) Wolfram Research, Inc.: Mathematica 8.0, Champaign, Illinois (2010).

$$
\text { プロフィール }
$$

石澤伸夫 Nobuo ISHIZAWA

名古屋工業大学先進セラミックス研究センター

Advanced Ceramics Research Centre, Nagoya Institute of Technology

于 507-0071 岐阜県多治見市旭ヶ丘 10-6-29

10-6-29 Asahigaoka, Tajimi, Gifu 507-0071, Japan

e-mail: ishizawa@nitech.ac.jp 